\title{
Tourism inter-industry linkages in the Lao PDR economy: an input-output analysis
}

\author{
BHOJ RAJ KHANAL
}

Department of Economics and Finance, Faculty of Commerce, Lincoln University, New Zealand, and Lutheran World Federation Nepal, PO Box 3330, Mabarajgunj, Kathmandu, Nepal. E-mail: bhojrajkhanal@gmail.com. (Corresponding author.)

\section{CHRISTOPHER GAN}

Department of Economics and Finance, Faculty of Commerce, PO Box 85084, Lincoln University, Lincoln 7647, Canterbury, New Zealand.

E-mail: christopher.gan@lincoln.ac.nz.

\section{SUSANNE BECKEN}

Griffith Business School, Griffith University, Australia, and Faculty of Environment, Society and Design, Lincoln University, New Zealand. E-mail: s.becken@griffith.edu.au.

This paper studies the significance of economic linkages between the Lao PDR tourism sector and the rest of the economy. An international visitors' expenditure survey and input-output models were used to disaggregate tourism economic data from the economy. A series of approaches was then employed to construct inter-industry linkage measures. The results reveal a rising trend in tourism's linkages with the country's economy from 2003 to 2008, indicating an increase in the tourism sector's dependency on the rest of the economy. The key sectors are food and beverages, manufacturing, wholesale and retail trade, agriculture and livestock, and tourism - these sectors dominated the economy during 2003-2008. The results provide evidence that the Lao PDR tourism sector is a key sector in enhancing economic growth and enabling the country to be one of the fastest growing economies in the Greater Mekong Subregion.

Keywords: input-output analysis; inter-industry linkages; key sector; Lao PDR 
Table 1. Key tourism indicators of the Greater Mekong subregion countries, 2010.

\begin{tabular}{lcccc} 
Country & $\begin{array}{c}\text { Tourism GDP } \\
(\%)\end{array}$ & $\begin{array}{c}\text { Tourism exports } \\
(\%)\end{array}$ & $\begin{array}{c}\text { Tourism jobs } \\
(\%)\end{array}$ & $\begin{array}{c}\text { Tourism GDP growth } \\
(\%)\end{array}$ \\
Cambodia & 18.4 & 26.8 & 14.3 & 4.9 \\
China & 9.2 & 3.3 & 7.7 & 6.5 \\
Lao PDR & 11.5 & 15.5 & 9.2 & 2.7 \\
Myanmar & 5.7 & 1.2 & 5.2 & 4.5 \\
Thailand & 13.9 & 10.8 & 10.4 & 1.6 \\
Vietnam & 12.4 & 6.7 & 9.9 & 3.4 \\
GMS Average & 11.9 & 10.7 & 9.5 & 3.9 \\
\hline
\end{tabular}

Source: World Travel and Tourism Council (2010) reports of the six GMS countries.

Over two million international tourists visited the Lao PDR in 2010, generating US\$313 million in tourism receipts (LNTA, 2010). The World Travel and Tourism Council (2010) estimated that tourism contributed $11.5 \%$ to the Lao PDR's GDP in 2010, which is similar to the Greater Mekong Subregion (GMS) average contribution (see Table 1). The tourism exports of Lao PDR were $15.5 \%$, the second highest among the GMS countries, following Cambodia at $26.8 \%$. The tourism sector in the Lao PDR generates about $9.2 \%$ of employment. In 2010, the GDP growth of the tourism sector was expected to be $2.7 \%$ in the Lao PDR compared with $3.9 \%$ average in the GMS (ADB, 2008).

The volume of tourism receipts increased threefold between 2003 (US $\$ 87$ million) and 2008 (US $\$ 276$ million), with an average annual growth of $22.9 \%$ (LNTA, 2009). The economic growth of the country as a whole has accelerated in the last eight years at an average growth rate of $7 \%$ per annum and with $8 \%$ in 2008 (UNWTO, 2008). Despite tourism's fast growth during the last decade in the country, there has been no quantifiable analysis of the Lao PDR's tourism sector linkages with the other economic sectors. No previous research has analysed tourism's economic linkages and the structural changes in Lao PDR using econometric models. For future planning and development, it is essential to understand how well the tourism sector has interlinked with the different economic sectors in the Lao PDR. Therefore, this paper investigates the effects of visitors' expenditure on the Lao PDR economy by assessing the inter-industry linkages and deriving the key sectors for 2003 and 2008.

The paper is organized as follows. Next, the second section briefly reviews research examining different approaches to inter-industry linkages and key sector analyses. The third section outlines the data and methods used in this study including the econometric model and the software used to determine the economic linkages and perform the key sector analyses. The fourth section presents and discusses the research results. This is followed by the conclusions, implications and limitations of the study, and areas for future research.

\section{Literature}

Identification of the significance of the inter-industry linkages of economic sectors is vital for development planning. Linkage analysis allows the comparison 
of different sectors of an economy in terms of the interdependence of their production structures (Pratt, 2011). Various econometric models have been used to measure economic linkages and the impact of tourism in an economy, such as input-output (I-O), the social accounting matrix (SAM) and the tourism satellite account (TSA). The statistical data available in the Lao PDR national accounts allow an economic analysis using the $\mathrm{I}-\mathrm{O}$ model approach. The I-O model quantifies the direct and indirect impacts and defines the ranking of economic sectors based on their linkage strengths. More specifically, I-O table rows show 'who gives to whom' and the columns show 'who receives from whom' (Bekhet, 2010) Thus, linkages using I-O models refer to the transactions among different economic sectors, for example, sectors that purchase and sell products to each other for production purposes. Linkages have three components: backward, forward and total linkages. The backward linkage index denotes the amount a sector demands from other sectors, whereas forward linkage index denotes how much a sector is demanded (Parré et al, 2002). The 'total linkages' is the sum of the backward and forward linkages (Azad, 1999). Measurement of the strengths of the linkages allows the identification of the key sectors in an economy.

Various researchers have used I-O models to estimate the linkages of the tourism sector in an economy. Rasmussen (1956), Hirschman (1958), and Chenery and Watanabe (1958) pioneered the measurement of linkages approach, which indicates the importance of the different economic sectors in terms of their direct impact on the whole system. Zhou et al (1997) applied both I-O and computable general equilibrium (CGE) models to the Hawaiian economy and identified the industries that are key to tourism. The I-O model is a major component of the SAM and an important 'database' for most CGE models (Lindberg, 2011). Guo et al (2005) and Cai et al (2006) supported Sonis et al's (1995a) findings that conventional and modern linkage approaches complement each other for linkage and key sector analyses. Cai et al (2006) developed a method to compute tourism's linkages using national, regional or local I-O tables and demonstrated its utility by applying it to Hawaiian economy.

Cella (1984), Sonis et al (1995a), Hewings et al (1998), Cai et al (2006), Midmore et al (2006) and other economists updated linkage and key sector analysis methods making the calculations widely applicable to verify how each sector's influence is distributed over the economy. Other studies that adopted I-O models using linkages and key sector analyses include Kula (2008), Kweka et al (2001, 2003), Secretario et al (2009), Matallah and Proops (1992) and Beynon et al (2009).

Reis and Rua (2006) reported that the I-O model provides a better measurement of both backward and forward linkages and key sector analysis since it could account for domestic linkages. The authors reported that service sectors obtained lower linkage values than industry sectors in Portugal.

Kweka et al $(2001,2003)$ used different multiplier and inter-industry linkage measures for Tanzania and reported that the sectors most important for tourism demand impacts were food and beverages, fishing, staple food, and wholesale and retail trade. Tourism achieved a significant backward linkage, third highest in the economy, and a forward linkage higher than the agriculture, manufacturing and other service sectors.

Using multiple inter-industry linkage approach, Secretario et al (2009) 
reported that two sectors for Cambodia (textile and transport), three sectors for Thailand (food and beverages, electricity-gas and transport) and four sectors for Vietnam (food and beverages, paper, non-metal and metal production) were key sectors in the 22 sectors in their economies. Matallah and Proops (1992) used both multiplier and linkage analysis measures and found that in Algeria the construction and service sectors were the key sectors but manufacturing, energy and water nearly qualified as key sectors.

Using Chenery-Watanabe, Rasmussen-Hirschman and eigenvector linkage measures, Beynon et al (2009) undertook analysis of 11 tourism related sectors in 79 economic sectors in the Welsh economy. Transportation, recreation and welfare, guest houses and non-service accommodation were considered the key sectors; they achieved greater values in backward and forward linkages than other economic sectors. Using total and pure linkages for China, Andreosso O'Callaghan and Yue (2004) found that the average linkages had increased from 1987-1997. High total linkage coefficients were concentrated mainly in the agriculture, manufacturing, construction and services sectors. Although the list of key sectors in the economy differs among the various approaches used in the study, the core key sectors comprised agriculture, textile, construction, primary metals, commerce, and other services. The authors chose the pure linkage method over the total linkage method for better results in identifying key sectors.

A key sector means that an increase in the final demand for the sector's output will have a large impact on the sectors that supply inputs to support the key sector's output (Drejer, 2003). Using the Rasmussen-Hirschman and Chenery-Watanabe linkage outputs, which consider only linkage effects without any consideration of the level of production in each sector, may result in misleading interpretation because a sector can be identified as a key sector because of its higher backward and forward linkages (Sonis et al, 1995a). The authors further suggested that the level of production is also important because it helps to determine which sectors will be responsible for changes in the macro-level measures of the economy. Hence multiple approaches need to be combined to derive better ways of explaining the linkages of an economy (Beynon et al, 2009; Cai et al, 2006; Sonis et al, 1995a; Surugiu et al, 2009).

\section{Data and methodology}

An initial attempt to compile the 1997 national I-O table for Lao PDR has been made earlier (Asra et al, 2006), however, owing to the unreliability of the data, the Lao National Statistical Centre withheld the publication. Since then, the country has been producing its national accounts annually. These are symmetrical with an I-O application. The first study on I-O data in the country was published in 2003 with the help of the Asian Development Bank. In addition, Asra et al (2006) in the Lao PDR and Saito and Kobayashi (2007) in four countries of the GMS (including Lao PDR) undertook I-O analyses that have estimated the economic impact on the regional/national economies. Sim et al (2007) used I-O models for both Savannakhet (Lao PDR) and Mukdaharn (Thailand) to compare the provinces' economic structure.

Tourism is not a distinct sector in the standard industrial classification 
system of the Lao PDR. This study therefore used procedures to disaggregate the tourism sector from the other economic sectors of the country's economy. The actual national gross inputs and outputs for 2003 and 2008 (National Statistics Centre (NSC), 2003, 2008) were employed to construct both years' national $\mathrm{I}-\mathrm{O}$ tables using the mixed approach (using both primary and secondary data). A visitors' expenditure survey collected demographic as well as expenditure details of international visitors departing the country. Visitors' expenditure was extrapolated based on the expenditure categories obtained from the survey.

The I-O coefficients of the 2003 I-O table were used to update the 2008 I-O table of the Lao PDR by the RAS method as per the requirements to balance the I-O tables. Row $(\mathrm{R})$ is called the row coefficient (substitution effects), column ( $\mathrm{S}$ ) is called the column coefficient (fabrication effects) for the sector (updated year) and ' $\mathrm{A}$ ' is $\mathrm{I}-\mathrm{O}$ coefficient of the base year. The RAS method is relatively simple and uses a bi-proportional matrix leading to minimum errors while estimating and updating I-O tables (United Nations, 1999). The data were analysed using SimSIP SAM software, a Microsoft Excelbased application with MATLAB applications that can be used to analyse I-O tables (Parra and Wodon, 2008). Previous studies that used the software for I-O analyses include Parra and Wodon (2009) for Tanzania; Fofana et al (2009) for Senegal; and Nganou et al (2009) for Kenya.

A total of 417 international visitors were surveyed during NovemberDecember 2009 in Lao PDR. The results obtained from the survey across allocated spending categories were extrapolated using data on total visitor arrivals, average length of stay and daily average expenditure. This generated data on expenditure by each spending category for each country of origin. Summing across the groups and categories and related economic sectors generated the total expenditure in the tourism sector. In this study, the $20 \times$ 20 sectors of the $2003 \mathrm{I}-\mathrm{O}$ table were aggregated into $14 \times 14$ sectors for both years; the emphasis has been given to the tourism related sectors in the country (see Table 2). The sector aggregation process followed the guidelines of the United Nations (1999) Handbook of Input Output Table Compilation and Analysis. The tourism economic data for the respective years were obtained from the 2003 and 2008 Tourism Year Books of the Lao PDR (LNTA, 2003, 2008).

Three analysis components were used in this study: (a) matrix design, update and balance I-O table sector impact; (b) inter-industry linkages and key sector analyses; and (c) the structural change of an economy. Of the 14 economic sectors, five endogenous government sectors (compensation of employees, production tax less subsidies, depreciation, operating surplus, import tax), four exogenous government sectors (household expenditure, government expenditure, gross fixed capital formation and changes in inventories), two rest of the world sectors (exports and imports) and one residual account, which is exogenous by construction, were identified and simulated for the 2003 and 2008 data for the economy.

A number of previous studies that used multiple methods of estimating linkages and analysing key sectors have yielded different results. This present study builds on Bocoum (2000), Kweka et al (2001, 2003), Beynon et al (2009) and Surugiu et al (2009) to define key sectors in ordinal terms (ranking the economic sectors based on their linkage strengths). A number of approaches to 
Table 2. Economic sector aggregations of the Lao PDR economy.

Sectors in Lao PDR national accounts Sectors used in this study

Code used in this study

Agriculture

1 Crops

2 Livestock, fisheries and poultry

3 Forestry and logging

Industry

4 Mining and quarrying

5 Food, beverage and tobacco manufacturing

6 Textiles, garments and leather products

7 Wood and paper products; printing

8 Chemical products; petroleum

9 Non-metallic mineral products

10 Metal products, machinery and parts

11 Other manufactured goods

12 Electricity and water supply

13 Construction

\section{Services}

\section{Transportation}

15 Postage and telecommunication

16 Wholesale and retail trade

17 Banking and insurance

18 Real estate and business services

19 Public administration

20 Personal, social and community services

\section{Agriculture}

1 Agriculture and livestock

2 Forestry and logging

AGRILIVE

FORESLOG

Industry

3 Mining and quarrying

4 Food and beverages

manufacturing

5 All other manufacturing
ALLMANUF ELECWATE

CONSTRUC

TRANCOMM

W\&RTRADE

BANKFINA

REALBUSI

PUBADMIN

PERSERVI

TOURISM

Note: ${ }^{a}$ The tourism sector is created as a new sector in Lao PDR economy.

estimate the sets of linkage measures have been developed within the I-O framework. Our study uses six linkage indices (Chenery-Watanabe linkage, Rasmussen-Hirschman linkage, pure linkage, weighted linkage, I-O multiplier product matrix and self sufficiency rate) to derive sector strengths and undertake key sector analysis of the Lao PDR economic sectors. These linkage measurement approaches are estimated as follows.

\section{Chenery-Watanabe inter-industry linkages}

The Chenery Watanabe linkage considers linkage effects without any consideration of the level of production of the economic sectors. Beynon et al (2009) reported that the approach gives the direct economic impacts and utilizes the row and column multipliers of the I-O matrices. The Chenery- 
Watanabe inter-industry linkages in our study are derived as Beynon et al (2009) (see Equations (1) and (2) in the Appendix).

\section{Rasmussen-Hirschman backward and forward linkages}

This linkage approach takes into account indirect economic effects, which are ignored in the Chenery-Watanabe approach (Miller and Blair, 2009). The sector with higher backward and forward linkage values represents the sector with the higher effect on the demand for domestic production and the larger impact in the economy (Cai and Leung, 2004). A linkage value above one of a sector indicates that the sector draws more than average from the economic system and a value below one means the sector draws less than average (Parra and Wodon, 2008). These linkages in this study are estimated using Equations (3) and (4) (see Appendix as Bonet (2005), Parré et al (2002) and Sonis et al (1995a).

The interpretations of linkages are as follows: key sectors: both $B L$ and $F L>1$; backward oriented sectors: $B L>1$ and $F L<1$; forward oriented sectors $B L<1$ and $F L>1$; and weak sectors $B L<1$ and $F L<1$.

Total linkages are the backward and forward linkages of each sector, which represents both the direct and indirect capacity of the services to increase economic activity throughout the economy following an increase in their own demand (Azad, 1999). Total linkages provide an alternative basis for comparison; the sectors that have the greatest values are considered key sectors of the economy (Sonis et al, 1995a).

\section{Pure linkages}

Pure linkages measured in monetary terms are weight factors of the sector's linkage power (Parra and Wodon, 2008). The pure linkage index of backward, forward and total linkages measures the importance of a given sector to the rest of the economy in terms of the sector's total output. Pure backward and forward linkages are shown in Equations (5) and (6) (see Appendix) (Bonet, 2005; Sonis et al, 1995a, 1995b).

\section{Weighted linkages}

Weighted linkage uses the relative importance of final demand and total sector output as weights while estimating the linkages of economic sectors. Drejer (2003) explained that introducing weights to the economic sector based on its production scale while calculating the linkages is the investment induced by the key sectors. The weighted linkages are calculated as Drejer (2003) (see Equations (7) and (8) in the Appendix).

\section{I-O multiplier product matrix (MPM)}

The I-O MPM provides the landscape of an economy showing the hierarchies of backward and forward linkages of the economic sectors (Bonet, 2005). The I-O MPM graph derives the economic sectors' ranking based on the size of the hierarchies of the values of both linkages. The MPM from the I-O tables is estimated using Equations (9) and (10) (see Appendix) (Bonet, 2005; Hewings et al, 1998). 


\section{Self-sufficiency rate (SSR) analysis}

Asra et al (2006) defined SSR for economic sectors as the ratio of total production to total domestic demand of an economy. The SSR values can be expressed in Equation (11) (see Appendix) (Asra et al, 2006; Secretario et al, 2009).

The SSR of an economic sector is interpreted as follows: SSR $\geq 1$ means that its output is sufficient to sustain its domestic demand. If the $S S R<1$, then the economic sector is an import oriented sector that relies on imports to meet the total domestic demand.

Our study estimates inter-industry linkage values and identifies key sectors of the Lao PDR economy based on both individual and combined indices of linkage measures. The multi ranked index (MRI) approach (Kweka et al, 2001, 2003) was modified and applied incorporating multiple linkage measures to derive tourism's overall position and identify key sectors of the Lao PDR economy. For this index, a new value was assigned to all linkage measure approaches of the 14 economic sectors based on their rankings. The values were assigned as follows: first five sectors were assigned a score of ' 3 ', the next five sectors a score of ' 2 ' and the remaining sectors a score of ' 1 '. After summing and averaging these values for the country's 14 economic sectors, the highest average scores are identified as key sectors (first five sectors), average sectors (next five sectors) and weak sectors (final four sectors).

\section{Results and discussion}

\section{Profile of surveyed respondents}

In terms of frequency of visits, $52 \%$ of the respondents made multiple visits to the country whereas $48 \%$ visited the country for the first time. Tourists visiting the Lao PDR as single day visitors contributed $8 \%$ of total arrivals. The majority of Thai, Vietnamese and Chinese visitors were day visitors. The results showed that the most common reasons for visiting the Lao PDR were for 'holiday and vacation' (58\%) followed by 'business and commercial purposes' $(13 \%)$, 'conferences and meetings' (8\%) and 'visiting families and friends' $(6 \%)$. Visitors from Thailand $(30 \%)$ had the shortest average stay in the Lao PDR (4.1 days/visit) whereas visitors from Vietnam spent 6.2 days per visit. Europeans and Americans stayed longer (9.3 days/visit) than the overall average, followed by visitors from other South East Asia, East Asia and Pacific countries. The results revealed that Thai and Vietnamese visitors stayed a shorter duration and spent less than the average expenditure. About $15 \%$ of the respondents stayed more than 10 days in the Lao PDR; the longest was 42 days. The average length of the stay was 6.8 days/trip.

\section{Expenditure patterns of international visitors}

The results showed the average amount spent by the respondents was US $\$ 246 /$ trip with an average daily expenditure of US\$36. Respondents spent $30 \%$ of their total expenditure in the accommodation sector, amounting to US\$84 million, and US\$69 million for food and beverages. This accounted for $25 \%$ 
Table 3. Expenditure in the Lao PDR of the respondents by country of origin, 2009.

\begin{tabular}{lcrrrrr} 
Sector & Thailand & Vietnam & $\begin{array}{r}\text { China } \\
\text { ROM }\end{array}$ & $\begin{array}{r}\text { Euro } \\
\text { Ame }\end{array}$ & $\begin{array}{r}\text { SEA, } \\
\text { EA, PA }\end{array}$ & $\begin{array}{c}\text { Rest of } \\
\text { world }\end{array}$ \\
Accommodation & 26.4 & 33.7 & 31.29 & 28.0 & 27.8 & 27.5 \\
Food and beverages & 26.6 & 25.0 & 22.55 & 18.4 & 18.7 & 17.8 \\
Shopping/retail trade & 17.3 & 9.6 & 10.81 & 9.8 & 10.2 & 10.5 \\
Local transportation & 10.1 & 11.1 & 9.76 & 10.6 & 11.3 & 10.1 \\
Sight seeing & 4.2 & 5.8 & 6.51 & 6.8 & 8.8 & 5.5 \\
Recreational activities & 9.8 & 8.3 & 8.18 & 7.3 & 7.8 & 6.4 \\
Communications & 4.0 & 4.7 & 5.65 & 4.4 & 5.1 & 5.9 \\
Visa fee & 0.0 & 0.0 & 3.44 & 11.3 & 6.3 & 12.5 \\
Miscellaneous & 1.6 & 1.7 & 1.79 & 3.5 & 3.9 & 3.8 \\
Total & 100.0 & 100.0 & 100.0 & 100.0 & 100.0 & 100.0 \\
\hline
\end{tabular}

Note: $N=417$ (figures are percentages). Euro Ame = European and American countries; other SEA = Singapore, Malaysia, Indonesia and Philippines; EA PA = East Asia and the Pacific; ROM = Rest of the Mekong (Cambodia and Myanmar).

Source: Visitors' Expenditure Survey, 2009.

of the total expenditure. Further, a total of US $\$ 36$ million (13\% of total expenditure) was spent in the retail trade sector and US\$4 million on entertainment and recreation (16\%). Finally, visitors spent US\$13 million (5\%) on transportation, US\$11 million (4\%) on banking and communication related expenses and US $\$ 17$ million $(6 \%)$ on visa fees and miscellaneous expenses.

Forty-two per cent of the total arrivals in the Lao PDR were from Thailand (495,000 visitors, 30\%) and Vietnam (233,000 visitors, 13\%) followed by other South East Asian, East Asian and Pacific countries (358,000 visitors, 22\%), Europe and America (325,000 visitors, 19\%), China, Cambodia and Myanmar (254,000 visitors, $14 \%)$, and the Rest of the World (70,000 visitors, 5\%). The results indicated that the country received the majority of its visitors from other GMS countries, South East Asian (SEA) countries (Indonesia, Malaysia, Singapore and Philippines), European and American (Canada and USA) countries, East Asian (Japan and South Korea) and Pacific countries (Australia and New Zealand).

Table 3 shows the visitors' expenditure patterns based on their country of origin. Thailand, the biggest proportion of the Lao PDR's international visitor arrivals, spent less on accommodation (26\%) but had relatively higher expenses on food and beverages (27\%). Thai visitors spent more on retail trade (17\%) and recreational activities (10\%) than other visitors. Other countries' visitors spent more on accommodation: Europe and America (28\%); other SEA countries, East Asia and the Pacific (28\%) and the Rest of the World (27\%). All respondents, except the visitors from other SEA member countries, paid visa fees on entering the Lao PDR, typically ranging from US $\$ 8$ to 42 per trip and person (LNTA, 2009). Visitors from Europe and America spent more on miscellaneous expenses than other visitors. Visitors from GMS countries spent more on 'entertainment and recreational' activities whereas visitors from Europe, America and other SEA countries spent more on sightseeing and transportation. 
Table 4. Total gross receipts from visitor arrivals in the Lao PDR, 2009.

\begin{tabular}{lcccccr}
$\begin{array}{l}\text { Country/region } \\
\text { of origin }\end{array}$ & $\begin{array}{c}\text { Expenses/ } \\
\text { trip/ } \\
\text { tourist } \\
\text { (US\$) }\end{array}$ & $\begin{array}{c}\text { Duration } \\
\text { of stay } \\
\text { per trip } \\
\text { (days) }\end{array}$ & $\begin{array}{c}\text { Expenses } \\
\text { per tourist } \\
\text { per day } \\
\text { (US\$) }\end{array}$ & $\begin{array}{c}\text { Total } \\
\text { tourists } \\
\text { (million) }\end{array}$ & $\begin{array}{c}\text { Estimated } \\
\text { income } \\
\text { (million } \\
\text { US\$) }\end{array}$ & $\begin{array}{r}\text { Total } \\
\text { receipts } \\
(\%)\end{array}$ \\
Thailand & 140.4 & 4.10 & 34.25 & 0.4956 & 69.72 & 16.78 \\
Vietnam & 169.4 & 6.13 & 27.64 & 0.2332 & 39.59 & 9.53 \\
China, ROM & 205.4 & 7.16 & 28.69 & 0.2540 & 52.29 & 12.58 \\
Europe America & 337.0 & 9.33 & 36.12 & 0.3249 & 109.70 & 26.40 \\
SEA, EA, PA & 341.4 & 8.88 & 38.44 & 0.3582 & 122.50 & 29.48 \\
Rest of the World & 304.6 & 7.94 & 38.36 & 0.0708 & 21.61 & 5.20 \\
Average & 245.59 & 6.83 & 35.96 & 1.7367 & 415.50 & 100.0 \\
\hline
\end{tabular}

Source: Visitors' Expenditure Survey, 2009.

Table 4 shows the total gross receipts from visitor arrivals in the Lao PDR. GMS countries provide more arrivals (56\%), but shorter stays, so ultimately they represent a lower share in tourism receipts (40\%). Thailand has a $30 \%$ share of visitor arrivals but the total receipts amounted to about 17\% (US\$69 million). Vietnam had over $13 \%$ of total arrivals but contributed only $10 \%$ of total tourism receipts (US\$39 million). China, Cambodia and Myanmar jointly accounted for $15 \%$ of total arrivals but their contribution to total tourism receipts was only $13 \%$ (US\$52 million). Visitors from Europe, America, other SEA, East Asia and the Pacific had a higher share of tourism receipts because of their longer stays and higher average daily expenditure (see Table 4).

\section{Tourism macro-economic indicators of Lao PDR}

International visitor arrivals increased 2.7 times from 2003 to 2008, and tourism receipts increased at an even greater rate of 3.2 times. In 2008, tourism was the third largest sector after the agriculture and livestock, and forestry and logging sectors, employing about 19,000 people directly and 12,000 indirectly. Further, tourism accounted for $8.4 \%$ of business taxes and contributed $7.5 \%$ to the national GDP, ranked fourth largest among the 14 economic sectors of the country in GDP contribution. The three other sectors that contributed significantly to the GDP were agriculture and livestock (17\%), food and beverages manufacturing (16\%) and the wholesale and retail trade (12\%). The macro-economic indicators derived from $\mathrm{I}-\mathrm{O}$ analysis showed that tourism impacted positively on the economy from 2003 to 2008.

\section{Inter-industry linkages of the tourism sector in the Lao PDR economy}

\section{Chenery-Watanabe inter-industry linkage approach}

The Chenery-Watanabe linkage approach revealed that the average backward and forward linkages increased between 2003 and 2008. This shows an increasing 
degree of sector interdependence together with high economic growth and a more diverse economy between the study years. Of the 14 economic sectors, the tourism sector ranked fourth in 2003 with 2.694 and third in 2008 with 2.921. The total linkages showed the wholesale and retail trade (3.442); tourism (2.921); mining and quarrying (2.781); and forestry and logging (2.771) sectors were the most improved sectors in 2008. The results also showed that tourism's interaction with the other economic sectors increased by 23 cents per US $\$ 1$ spent indicating a higher dependency of tourism on the intermediate inputs over the five years.

\section{Rasmussen-Hirschman linkage and total linkage approaches}

Figures 1 and 2 show the backward and forward linkages of the Lao PDR economy in 2003 and 2008, respectively. The wholesale and retail trade sector was the only key sector in 2008. Tourism was one of the strongest backward oriented sectors in the economy for both years alongside electricity and water supply, transport and communication, construction, and food and beverages manufacturing sectors. The sectors with high backward linkages depend more on intermediate goods, which are typically capital intensive. Additionally, the tourism sector showed relatively high indices of the power of dispersion indicating higher backward linkage effects $(1.09,2003$ and 1.24, 2008) that result in higher output multipliers in the country's economy. The tourism sector together with the other three economic sectors, showed a significant increment in the total linkages value in 2008 compared with 2003. The difference, +0.14 , for the tourism linkages value, indicates that tourism's interactions with other economic sectors increased by $14 \%$ during the five years (14 cents more generated as linkage effects from a dollar's expenditure by an international visitor).

As reported by Pratt and Kay (2006), backward linked sectors are more important than forward linked sectors because backward linked sectors influence the rest of the economy through multiplier effects. Backward oriented sectors are relatively more stable than forward linked sectors (Bonet, 2005). The tourism sector's higher backward linkage value is also associated with the high employment and a larger output indicating that the sector purchases more inputs from the Lao PDR economy. Agriculture and livestock, mining and quarrying, and banking and finance were forward oriented sectors. The rest were weak sectors in 2008.

In forward linkages, the tourism sector ranked fifth of the 14 economic sectors for both years. The average forward linkage index indicates that the sector has a medium capacity to sell its products to other sectors; the tourism sector's inputs are mainly used for personal consumption and to provide final goods to the economy. Forward linkages are supply oriented. Tourism is one of the four sectors that had high backward linkage values for both years in the Lao PDR economy. This implies that tourism, as a purchaser of inputs, increased more than the average of all economic sectors in the economy for both years. The economic sectors that exhibit higher backward linkages are the sectors that are more connected with the industrial sectors (Azad, 1999). Vavrla and Rojicek (2006) reported that the industry with the highest value of backward linkages represents the industry with the highest effect on domestic production. 


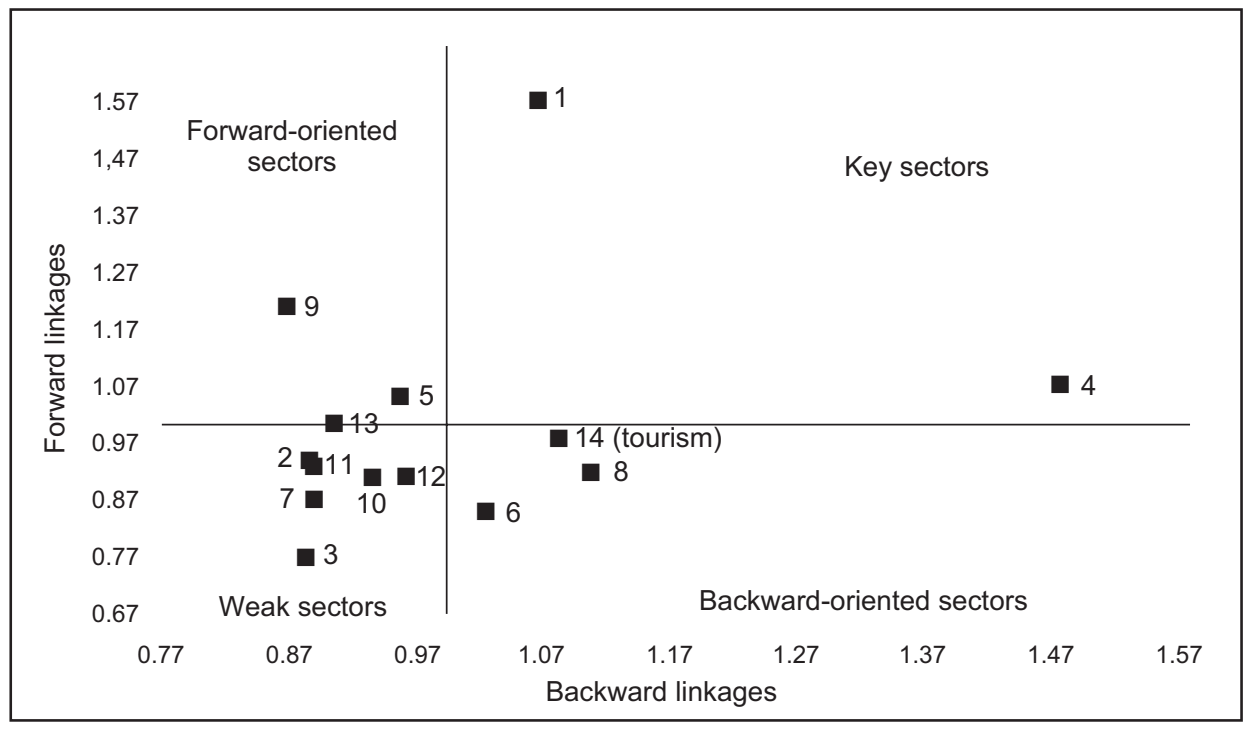

Figure 1. Backward and forward linkages in the Lao PDR economy in 2003. Note: 1-14 show the economic sectors of Lao PDR (see details in Table 2). Sector numbers are used instead of sector names in order not to overcrowd the figure.

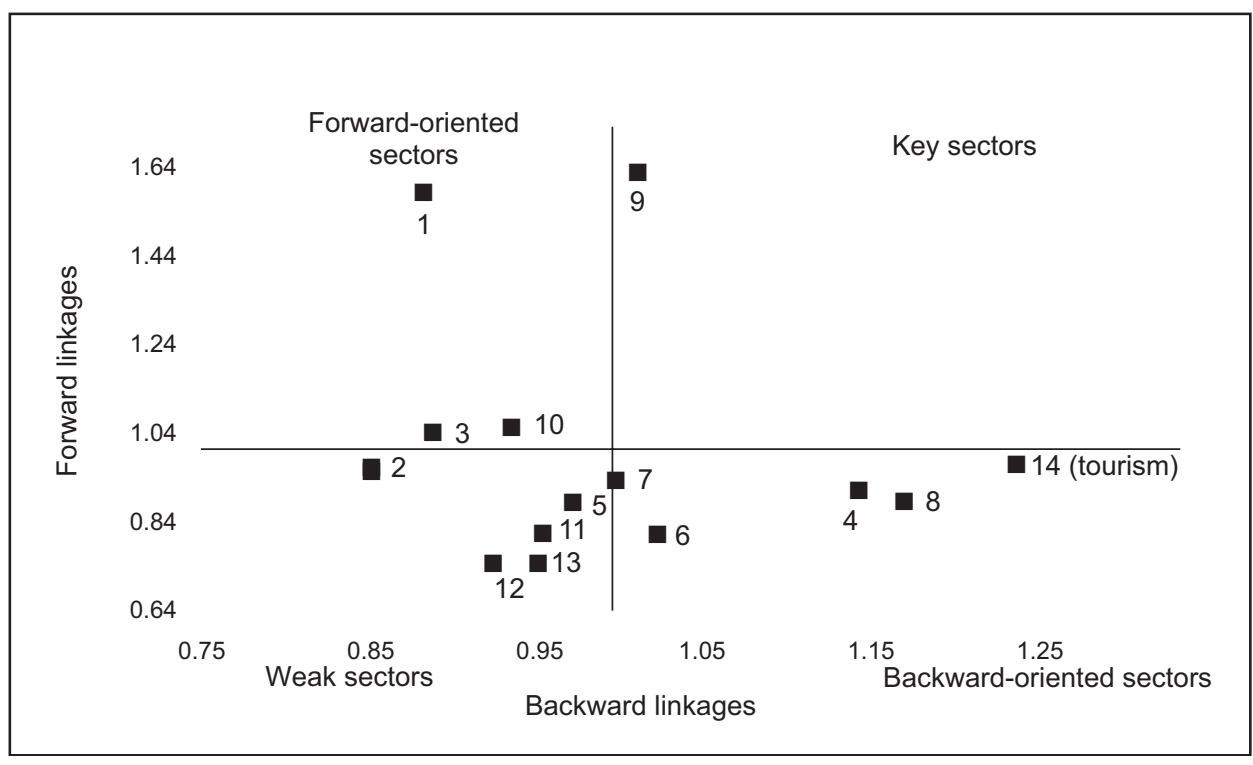

Figure 2. Backward and forward linkages in the Lao PDR economy in 2008. Note: 1-14 show the economic sectors of Lao PDR listed in Table 2.

Arabsheibani and Delgado-Aparicio (2002) explained that weak backward and forward linkages between sectors indicate that the economy is poorly integrated and depends on imports. 
Table 5. Total linkages of the Lao PDR economic sectors, 2003 and 2008.

Economic sectors

Agriculture and livestock

Forestry and logging

Mining and quarrying

Food and beverages manufacturing

All other manufacturing

Electricity and water supply

Construction

Transport and communication

Wholesale and retail trade

Banking, finance and insurance

Real estate and business services

Public administration

Personal, community and social services

Tourism
TL (2003)

2.419

1.959

1.966

2.079

1.908

1.992

1.904

1.916

2.433

1.941

1.848

1.800

1.770

2.065
Rank

TL (2008)

Rank

Note: $\mathrm{TL}=$ total linkages. The strongest backward and forward-linked sector ranked as 1 and the least as 14 in this study.

The aggregation of backward and forward linkages provides an alternative basis for identifying key sectors in the economy (Table 5). Among the 14 economic sectors of the Lao PDR in 2003, the wholesale and retail trade, agriculture and livestock, food and beverages manufacturing and the tourism sectors had the highest total linkages. The electricity and water supply, mining and quarrying, forestry and logging, and banking and finance sectors were average sectors in 2003 . The remaining six sectors were weak sectors. Similarly in 2008, the tourism sector, along with wholesale and retail trade, agriculture and livestock, and the transport and communication sectors, achieved relatively higher total linkages values. The banking and finance, food and beverages manufacturing, construction, and mining and quarrying sectors obtained higher linkages values than the average of all sectors. The rest of the economic sectors achieved lower linkage values than the average of all sectors in 2008. The results show that tourism ranked fourth in 2003 with a value of 2.06 of total linkages and moved up to third in 2008 (2.21 of total linkages). The more linkages exist between tourism and the general economy, the more innovative the tourism cluster will be (Lejarraja and Walkenhorst, 2007). Economic sectors with relatively high linkages offer greater potential to stimulate the economic activity of other sectors and therefore have a greater effect on economic growth (Jones, 1976).

Overall, in the study years, except the food and beverages manufacturing sector, the industry sector does not have particularly strong linkages with the rest of the economy even though the sector relies on imported inputs. The industry sector is underdeveloped and largely dominated by the mining and quarrying sector. The agriculture sector produces traditional outputs from subsistence farming in the country with low levels of value added. Mining and quarrying (industry) and forestry and logging (agriculture) do not possess great linkages although these sectors produce the highest level of outputs, mainly for 
Table 6. Pure linkages of the economic sectors of the Lao PDR, 2008.

\begin{tabular}{lcclrlllr}
\hline Sectors & PBL & Rank & Sectors & PFL & Rank & Sectors & PTL & Rank \\
FOODBEV & 425.08 & 1 & AGRILIVE & 463.69 & 1 & AGRILIVE & 796.9 & 1 \\
AGRILIVE & 333.2 & 2 & W\&RTRA & 374.56 & 2 & W\&RTRA & 657.1 & 2 \\
W\&RTRAD & 282.5 & 3 & BANKFIN & 241.07 & 3 & FOODBEV & 623.2 & 3 \\
MINEQYA & 211.16 & 4 & ALLMAN & 209.87 & 4 & ALLMAN & 419.5 & 4 \\
ALLMAN & 209.65 & 5 & FOODBEV & 198.07 & 5 & MINEQYA & 408.0 & 5 \\
TOURISM & 179.11 & 6 & MINEQYA & 196.82 & 6 & TOURISM & 337.8 & 6 \\
FORESLO & 164.88 & 7 & TOURISM & 158.67 & 7 & BANKFIN & 333.6 & 7 \\
PUBADMI & 157.55 & 8 & FORESLO & 153.27 & 8 & FORESLO & 318.2 & 8 \\
CONSTRU & 141.86 & 9 & CONSTRU & 148.34 & 9 & CONSTRU & 290.2 & 9 \\
ELECWAT & 139.85 & 10 & ELECWAT & 134.57 & 10 & ELECWAT & 274.4 & 10 \\
TRACOM & 131.63 & 11 & TRACOM & 117.76 & 11 & TRACOM & 249.4 & 11 \\
PERSERV & 94.73 & 12 & PERSERV & 83.09 & 12 & PUBADMI & 226.4 & 12 \\
BANKFIN & 92.52 & 13 & REALBUS & 70.81 & 13 & PERSERV & 177.8 & 13 \\
REALBUS & 92.39 & 14 & PUBADMI & 68.85 & 14 & REALBUS & 163.2 & 14 \\
Total & $2,656.1$ & & & $2,619.4$ & & & $5,275.5$ & \\
\hline
\end{tabular}

Note: Linkage values are in US\$ million.

exports. The banking and finance, and construction sectors grew fast but relied substantially on imported goods and foreign employees, so registered lower linkages. Tourism, together with the wholesale and retail trade and electricity and water supply, are the most improved sectors between 2003 and 2008 in terms of exhibiting high linkages.

\section{Pure linkage indices}

Table 6 shows the pure backward and forward linkage values of the economic sectors in the Lao PDR economy in 2008. The tourism sector ranked sixth, generating a total value of US\$179 million of pure backward linkage effects and seventh with a total value of US\$158 million of pure forward linkage effects in the country's economy. The tourism sector generated total pure linkages of US $\$ 337$ million. In 2008, the food and beverages manufacturing sector yielded the highest pure backward linkages and agriculture and livestock yielded the highest pure forward linkages. The agriculture and livestock, wholesale and retail trade, and the food and beverages manufacturing sectors were the three most important sectors in 2008.

Parra and Wodon (2008) reported that pure linkage is used for a direct comparison of the relative importance of the economic sectors with the volume of production and monetary values. For example, for the tourism sector, it indicates the total output driven by the tourism as pure linkages to the different economic sectors excluding the effect of the tourism sector itself. In relative terms in 2003, the three most prominent sectors based on pure linkages were food and beverages manufacturing, agriculture and livestock and construction. Comparing the total gross tourism receipts and total pure linkage effects of the tourism sector in the country, the total pure linkage effect of the sector was US $\$ 93$ million (total visitors' expenditure: US $\$ 87$ million) in 2003 , which 
Table 7. Weighted backward and forward linkages, Lao PDR, 2008.

\begin{tabular}{lcccccr}
\hline Sectors & TBL & Rank & TFL & Rank & TL & Rank \\
& & & & & & \\
AGRILIVE & 3.154 & 2 & 4.692 & 1 & 7.846 & 1 \\
FORESLOG & 0.509 & 9 & 0.458 & 7 & 0.966 & 9 \\
MINEQYAR & 0.548 & 7 & 0.454 & 8 & 1.002 & 8 \\
FOODBEVE & 4.347 & 1 & 3.051 & 2 & 7.398 & 2 \\
ALLMANUF & 0.546 & 8 & 0.917 & 5 & 1.462 & 5 \\
ELECWATE & 0.352 & 12 & 0.199 & 13 & 0.551 & 12 \\
CONSTRUC & 1.083 & 3 & 1.055 & 4 & 2.138 & 3 \\
TRANCOMM & 0.415 & 10 & 0.173 & 14 & 0.588 & 11 \\
W\&RTRADE & 0.767 & 4 & 1.145 & 3 & 1.912 & 4 \\
BANKFINA & 0.234 & 14 & 0.257 & 11 & 0.491 & 14 \\
REALBUSI & 0.253 & 13 & 0.250 & 12 & 0.503 & 13 \\
PUBADMIN & 0.395 & 11 & 0.300 & 10 & 0.694 & 10 \\
PERSERVI & 0.698 & 6 & 0.325 & 9 & 1.022 & 7 \\
TOURISM & 0.724 & 5 & 0.701 & 6 & 1.425 & 6 \\
\hline
\end{tabular}

Note: $\mathrm{TBL}=$ total backward linkage; $\mathrm{TFL}=$ total forward linkage; $\mathrm{TL}=$ total linkages.

increased to US $\$ 337$ million of total pure linkage effects (total visitors' expenditure: US\$275 million) in 2008 .

\section{Weighted linkage indices}

Table 7 shows the weighted linkage values of the economic sectors of the Lao PDR in 2008. Agriculture and livestock ranked first in both linkages followed by the wholesale and retail trade. In 2008, tourism ranked sixth in weighted total linkage, fifth in backward linkage and sixth in forward linkage among the 14 economic sectors. The wholesale and retail trade sector was a key sector whereas the tourism registered as the most highly backward oriented sector followed by the transport and communication, and electricity and water supply sectors. Food and beverages manufacturing and construction were backward oriented sectors in 2008 in contrast to 2003. The sectors with strong forward orientation in 2008 were the agriculture and livestock, mining and quarrying, and banking and finance. The remaining five sectors were weak sectors in 2008 . The increasing trends of both the weighted and pure linkage values show that the tourism sector relied more on domestic inputs in 2008 than in 2003. The findings of the weighted and pure linkages of the tourism were similar and revealed that the sector was an average performing sector that exhibited medium capacity to increase inputs from the rest of the economy.

\section{The economic landscape or I-O MPM of the Lao PDR economy}

The row in I-O MPM represents the hierarchy of forward linkages and the column provides the details of the backward linkages. For example, the sectors in the first column of the table are those with higher backward linkages in the economy whereas the sectors in the first row of the table have greater forward linkages and vice versa (see Figure 3). Each cell of the I-O table denotes its 


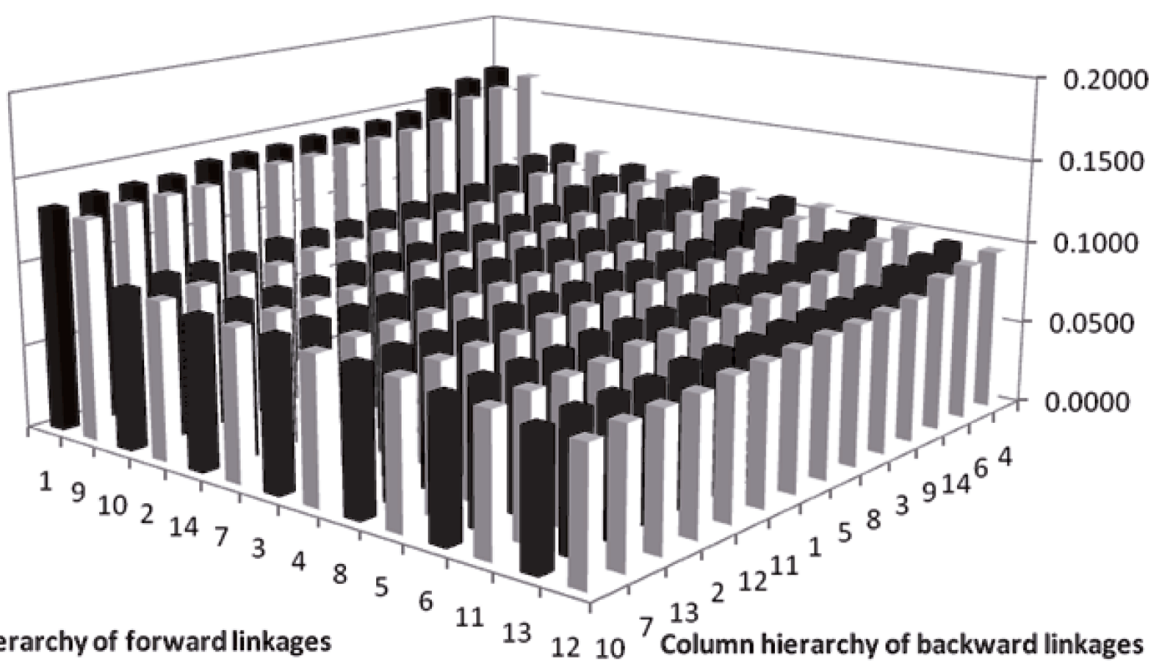

Figure 3. Economic landscape of the Lao PDR economy in 2008.

Note: Sector numbers are used instead of sector names in order not to overcrowd the figure (see Table 2).

first order change in the sum of all elements of the inverse matrix cause by the change in the I-O coefficients (Parra and Wodon, 2008).

Figure 3 shows the structure of the economic landscape of the Lao PDR economy in 2008. In the backward linkages, the tourism sector, along with food and beverages manufacturing, electricity and water supply, and wholesale and retail trade, were the four most important sectors in 2008. These sectors achieved higher hierarchies than the average of all sectors in the country. Tourism was the third most important sector based on the hierarchy of the backward linkages for both years in the economy. The sectors possessing average backward linkage hierarchies in the economy in 2008 were: mining and quarrying, transport and communication, other manufacturing, and real estate and business services. Agriculture and livestock, wholesale and retail trade, banking and finance, forestry and logging, and tourism achieved greater hierarchy of forward linkages in economy in 2008. The sectors exhibiting average hierarchies in the economy were construction; mining and quarrying; food and beverages; and transport and communication. The remaining sectors were weak sectors.

\section{Self-sufficiency rate of the Lao PDR economic sectors}

The SSR of all 14 economic sectors of the Lao PDR were computed for 2003 and 2008 (see Table 8). In 2003, only mining and quarrying and forestry and logging were self sufficient for domestic demand. In 2008, electricity and water supply, mining and quarrying and forestry and logging sectors were selfsufficient. The tourism sector ranked 11th in SSR in both years but its dependency on imports increased from 2003 to 2008. In percentage terms, the tourism sector was about $77 \%$ self-reliant in 2003 and this decreased to $64 \%$ 
Table 8. Self-sufficiency rates of economic sectors in the Lao PDR.

\begin{tabular}{lcccc}
\hline Economic sectors & 2003 & Rank & 2008 & Rank \\
Agriculture and livestock & 0.91 & 6 & 0.88 & 4 \\
Forestry and logging & 1.10 & 2 & 1.08 & 3 \\
Mining and quarrying & 2.23 & 1 & 2.50 & 1 \\
Food and beverage manufacturing & 0.98 & 3 & 0.79 & 7 \\
All other manufacturing & 0.75 & 12 & 0.82 & 6 \\
Electricity and water supply & 0.90 & 8 & 1.54 & 2 \\
Construction & 0.65 & 13 & 0.57 & 13 \\
Transport and communication & 0.91 & 7 & 0.55 & 14 \\
Wholesale and retail trade & 0.86 & 9 & 0.72 & 10 \\
Banking, finance and insurance & 0.93 & 5 & 0.63 & 12 \\
Real estate and business services & 0.98 & 4 & 0.85 & 5 \\
Public administration & 0.82 & 10 & 0.79 & 8 \\
Personal, social and community services & 0.64 & 14 & 0.73 & 9 \\
Tourism & 0.77 & 11 & 0.64 & 11 \\
Weighted average SSR & 0.89 & & 0.84 & \\
\hline
\end{tabular}

in 2008. The lower SSR values of the tourism sector revealed that the sector depended on imports for tourism goods and services, and significantly greater income leakages occurred through the economy in 2008 than in 2003.

Overall, the average value of the SSR of the service sectors was significantly lower than that of industry and agriculture sectors. The agriculture sector is more or less self-sufficient but the industrial and service sectors are not able to satisfy domestic demand. Compared with Secretario et al's (2009) study in Cambodia (0.93), Vietnam (0.97) and Thailand (1.03), Lao PDR's overall SSR value $(0.85)$ showed that the Lao PDR economy is relatively less self-sufficient.

Leakage and imports of tourism goods and services, by the Lao PDR tourism sector were also measured. Reis and Rua (2006) defined the leakage ratio as the ratio between the coefficient of leakage and the coefficient of interdependence. The coefficients of interdependence were 1.41 in 2003 and 1.54 in 2008 and the coefficients of leakage of 0.34 (2003) and 0.43 (2008) were computed for the economy. In percentage terms, the leakage ratios were $24 \%$ (2003) and $28 \%$ (2008) in the country's economy, which indicates that the tourism sector's leakages were relatively higher and the sector was less self sufficient in domestic production during the latter year of the study.

\section{Key sectors}

Table 9 shows the key sectors of Lao PDR economy for 2003 and 2008 based on the MRI approach. In 2003, the tourism sector, together with agriculture and livestock, food and beverages manufacturing, transport and communication, and the wholesale and retail trade sectors were the key sectors. Similarly, the food and beverages manufacturing, agriculture and livestock, wholesale and retail trade, tourism, and mining and quarrying sectors were key sectors in 2008. There was an increase in the final demand for these (key) sectors' outputs, 
Table 9. Key sectors of the Lao PDR economy based on the multi rank index approach.

Sectors 2003

Key

Food and beverages manufacturing

Agriculture and livestock

Tourism

Transport and communication

Wholesale and retail trade

Average

All other manufacturing

Electricity and water supply

Banking, finance and insurance

Forestry and logging

Public administration

Weak

Personal, community and social services

Construction

Real estate and business services

Mining and quarrying
2008

Food and beverages manufacturing

Agriculture and livestock

Wholesale and retail trade

Tourism

Mining and quarrying

Electricity and water supply

All other manufacturing

Forestry and logging

Transport and communication

Construction

Real estate and business services

Public administration

Banking, finance and insurance

Personal, community and social services

which will have a greater impact on the sectors that supply inputs for the production of these sectors' outputs in the economy. Further, the significant backward linkage of the tourism sector showed its influence was widely distributed in the Lao PDR economy.

The construction, personal, social and community services, public administration and real estate and business services exhibited weak linkages. These sectors' final demand increments will have significantly lower impacts on the sectors that supply inputs in the production of these sectors' outputs, which are characterized by high imports of goods and services and a high level of foreign ownership. The results shows that three of the five key sectors in 2008 were in the services sector (tourism, wholesale and retail trade, and electricity and water supply) but only two were key sectors in 2003 (tourism and wholesale and retail trade). The structure of the economy, as shown by the key sector interactions, had shifted from the agriculture and industry sectors to the service sectors providing evidence that the services sectors' beginning to dominate in Lao PDR economy during the five years.

One common finding of the linkage analysis methods was that tourism exhibited strong backward linkages in both years. Based on the MRI approach, the tourism sector ranked third in 2003 and fourth in 2008 in the key sector analysis of the economy. The common key sectors for both years were tourism, food and beverages manufacturing, wholesale and retail trade and agriculture and livestock. These sectors demonstrated greater values of linkages than other economic sectors and possess greater influence through both purchases and sales in the economy.

The respective rankings of the linkages and the key sectors of the Lao PDR economic sectors varied with the different methods used in our study. This shows some inconsistencies from the policy perspective, particularly where a sector is a key sector in one linkage approach and not in another. Therefore, our study defined key sectors based on both individual and combined ranking 
of linkage strengths. However, the MRI approach incorporated all linkage indicators used in this study and provided better results and insights into the linkage and key sector analyses. The different results of these linkage approaches are also caused by, to some extent, the different methodologies. Our study suggests that the different inter-industry linkage methods used in this study do not replace each other for linkage and key sector analyses of the economy, rather they complement each other. Further, the multiple indicators of the linkages used in our study have exhibited consistent and more widely applicable outcomes. Our findings also support and complement the findings of the Sonis et al (1995a), Beynon et al (2009), Cai and Leung (2004), Kweka et al (2001, 2003), and Kula (2008) using a set of approaches in identifying the key sectors in an economy.

\section{Conclusion}

International visitor arrivals and total tourism receipts increased significantly in the Lao PDR between the two study years. Since 2001, tourism ranked as the second most significant sector in the foreign exchange earnings in the country after mining and quarrying. The higher values of macro-economic indicators such as employment, GDP contribution and output generation for tourism showed that the sector has gained more importance in the country's economy in 2008 than in 2003. This attests to the significance of tourism's potential to enhance economic growth in the development of the Lao PDR.

Using Chenery-Watanabe, Rasmussen-Hirschman, and the I-O MPM linkage measures, this study found that tourism was within the top four sectors for both years. In pure and weighted linkages, the tourism sector was an average performing sector. This is because the majority of the tourism products and services were used as final demand for personal consumption. In terms of SSR, the tourism sector ranked low in both years because of higher income leakages through a significant number of foreign employees and the import of luxury goods in the hotel and accommodation sectors. Based on the MRI approach, in 2003, the food and beverages manufacturing, agriculture and livestock, tourism, transport and communication and wholesale and retail trade were all key sectors in the economy. In 2008, the food and beverages, agriculture and livestock, wholesale and retail trade, tourism and mining and quarrying were the key sectors. Tourism, together with the wholesale and retail trade, agriculture and livestock, and food and beverages manufacturing, were the four common key sectors for both years. These sectors have thus dominated changes in the economy over the five-year period. The number of key sectors from the service sector has increased from two to three between 2003 and 2008, indicating a shift from an agricultural and industrial economy to one influenced more by the provision of services.

The tourism sector's linkages were stronger in 2008 than in 2003 due to the significant increment in the sector's backward linkages. Tourism is one of the four most important sectors; it had one of the highest backward linkages values of all inter-industry linkages measured in our study. This indicates that there was a positive relationship between the increase in tourism's linkages and the growth of production activities in the domestic economy. Tourism falls into 
the group of 'relatively average forward linkage' sectors because most of the products of the sector are used for final consumption. The tourism sector has increased linkage effects more than other economic sectors therefore its expansion is advantageous to the economy. Further, there were substantial linkages between tourism and the rest of the economy therefore the tourism sector is potentially important in the country's economy.

Tourism is a multi-sector industry and its demand impacts several sectors in the economy. Therefore, policy and development programs should be directed at the strong inter-linked sectors with tourism, such as construction, tourism, wholesale and retail trade, and finance, banking and insurance. Despite the global economic recession, the growth prospects of the national economy and the tourism sector of Lao PDR remain positive. The country estimated its $8.5 \%$ overall economic growth in 2011 to be the highest among the GMS countries (ADB, 2011). We conclude that the economic benefits of the tourism industry are positive and its expansion will stimulate faster economic growth for the Lao PDR economy.

\section{Research implications}

The study compared tourism linkage indicators for two calendar years. Understanding tourism's linkage strength to the other economic sectors helps other sectors to be better informed of different economic sectors' needs, opportunities, and avoid possible supply bottlenecks in the Lao PDR economy. This helps to adjust the production structure of the tourism businesses to meet future tourism demands in the country. Our study findings suggest the need for the Lao PDR government and private sector to promote and invest in those tourism interlinked sectors such as accommodation, food and beverages, entertainment and retail trade establishments that are well inter-linked with the general economy. Particularly, the government should pay attention to the creation of the necessary conditions for the development of such linkages that will help reduce the import of tourism goods and services considerably. This study enhanced the procedures for estimating linkages and key sector analyses to quantify the economic contribution of tourism's linkages in an economy. The results are useful for highlighting the importance of the tourism sector for the Lao PDR economy and also its multiplier effects due to linkages to other economic sectors. This analysis is also useful for policymakers in other developing countries who seek to better understand the role of their tourism sector. Our findings are supported by other studies using the same approach.

\section{Limitations and areas of future research}

The national accounts of Lao PDR do not identify tourism as a distinct sector. At present, the country lacks tourism statistical data that can fulfil the requirements of the TSA. Our study also highlights the difficulties of obtaining information for this kind of research in developing countries. The country's national accounts were compatible with $\mathrm{I}-\mathrm{O}$ tables that made possible to use the I-O model in the study. However, there has been progress in the Lao PDR 
towards upgrading tourism statistics in line with UNTWO recommended satellite accounts (UNWTO, 2009). A better understanding of the country's economy requires in-depth economic linkage studies between changes in production, consumption and the income distribution.

\section{References}

ADB (2008), Tourism Sector in Greater Mekong Subregion, Asian Development Bank, Manila. ADB (2011), Key Indicators of Asia and the Pacific 2011, Asian Development Bank, Manila. Andreosso O'Callaghan, B., and Yue, G. (2004), 'Intersectoral linkages and key sectors in China', Asian Economic Journal, Vol 18, No 2, pp 165-183.

Arabsheibani, R., and Delgado-Aparicio, A. (2002), 'Tourism multiplier effects on Peru', Brazilian Journal of Business Economics, Vol 2, No 3, pp 31-45.

Asra, A., Secretario, F.T., and Suan, E.B. (2006), Development of an Input Output Framework: An Application to Savannakhet, Lao PDR, Asian Development Bank, Manila.

Azad, A.K. (1999), Inter-industry Linkages of Services in the Bangladesh Economy (With a Case Study of the Ready-made Garments Industry) and Potential Services Trade, World Bank, Washington, DC.

Bekhet, H.A. (2010), 'Ranking sector changes of the Malaysian economy: input output approach', International Business Research, Vol 3, No 1, pp 107-130.

Beynon, M., Jones, C., and Munday, M. (2009), 'The embeddedness of tourism-related activity: a regional analysis of sectoral linkages', Urban Studies, Vol 46, No 10, pp 2123-2141.

Bocoum, B. (2000), The Mineral and Energy Sectors and Stages of Economic Development: A Comparative Input Output Analysis, African Development Bank, Abidjan.

Bonet, J. (2005), Regional Structural Changes in Columbia: An Input Output Approach, Borradores de Economia, Cartagena.

Cai, J., and Leung, P.S. (2004), 'Linkage measures: a revisit and a suggested alternative', Economic System Research, Vol 16, No 1, pp 65-85.

Cai, J., Leung, P.S., and Mak, J. (2006), 'Tourism's forward and backward linkages', Journal of Travel Research, Vol 35, No 1, pp 36-52.

Cella, G. (1984), The Input Output Measurement of Inter-industry Linkages (1468-0084), Oxford Bulletin of Economics and Statistics, Vol 46, Blackwell, London.

Chenery, H.B., and Watanabe, T. (1958), 'International comparisons of the structure of production', Econometrica: Journal of the Econometric Society, Vol 26, pp 487-521.

Drejer, I. (2003), Input Output Based Measures of Inter-industry Linkages Revisited, Department of Business Studies, Aalborg University, Aalborg.

Fofana, I., Parra, J.C., and Wodon, Q. (2009), Exports and Labour Income by Gender: A Social Accounting Matrix Analysis for Senegal, World Bank, Washington, DC.

Guo, J., Hewings, G.J.D., and Sonis, M. (2005), 'Integrating decomposition approaches for the analysis of temporal changes in economic structure: an application of Chicago's economy from 1980 to 2000', Economic System Research, Vol 17, pp 297-315.

Hewings, G.J.D., Sonis, M., Guo, J., Israilevich, P.R., and Schindler, G.R. (1998), 'The hollowing out process in the Chicago economy, 1975-2011', Geographic Analysis, Vol 30, No 3, pp $217-$ 233.

Hirschman, A. (1958), The Strategy of Economic Development, Yale University, London.

Jones, L. (1976), 'The measurement of Hirschmanian linkages', Quarterly Journal of Economics, Vol 90, No 2, pp 323-333.

Kula, M. (2008), 'Supply use and input output tables, backward and forward linkages of the Turkish economy', paper presented at the Meeting of the 16th In-forum World Conference in Northern Cyprus, 1-5 September.

Kweka, J., Morrissey, O., and Blake, A. (2001), Is Tourism a Key Sector in Tanzania? Input Output Analysis of Income, Output, Employment and Tax Revenue, Christel DeHaan Tourism and Travel Research Institute, Nottingham.

Kweka, J., Morrissey, O., and Blake, A. (2003), 'The economic potential of tourism in Tanzania', Journal of International Development, Vol 15, No 3, pp 335-351.

Lejarraja, I., and Walkenhorst, P. (2007), Diversification by Deepening Linkages with Tourism, International Trade Department, The World Bank, Washingotn, DC.

Lindberg, G. (2011), Linkages: Economic Analysis of Agriculture in the Wider Economy, Department of Economics, Swedish University of Agricultural Sciences, Uppsala. 
LNTA (2003), Statistical Report on Tourism in Lao PDR, Lao National Tourism Authority, Vientiane. LNTA (2008), Statistical Report on Tourism in Lao PDR, Lao National Tourism Authority, Vientiane. LNTA (2009), Statistical Report on Tourism in Lao PDR, Lao National Tourism Authority, Vientiane. LNTA (2010), Statistical Report on Tourism in Lao PDR, Lao National Tourism Authority, Vientiane. Matallah, K., and Proops, J.L.R. (1992), 'Algerian economic development, 1968-1979: a multiplier and linkage analysis', Economic System Research, Vol 4, No 3, pp 257-268.

Midmore, P., Munday, M., and Roberts, A. (2006), 'Assessing industry linkages using regional input output tables', Regional Studies, Vol 40, No 3, pp 329-343.

Miller, R.E., and Blair, P.D. (2009), Input Output Analysis: Foundation and Extensions, Cambridge University Press, Cambridge.

National Statistics Centre (NSC) (2003), Statistical Year Book of Lao PDR 2003, National Statistics Centre, Vientiane.

National Statistics Centre (NSC) (2008), Statistical Year Book of Lao PDR 2008, National Statistics Centre, Vientiane.

Nganou, J.P., Parra, J.C., and Wodon, Q. (eds) (2009), Oil Price Shocks, Poverty and Gender: A Social Accounting Matrix Analysis for Kenya, World Bank, Washington, DC.

Parra, J.C., and Wodon, Q. (2008), SimSIP SAM: A Tool for the Analysis of Input Output Tables and Social Accounting Matrices, World Bank, Washington, DC.

Parra, J.C., and Wodon, Q. (2009), Comparing the Impact of Food and Energy Price Shocks on Consumer: A Social Accounting Matrix Analysis for Ghana, World Bank Policy Research Working Paper No. 4741, World Bank, Washington, DC.

Parré, J.L., Alves, A.F., and Sordi, J.C. (2002), Input Output Matrix for Metropolitan Areas Using Local Census Data: The Case of Maringa Brazil, Council for the Economical Development of Maringa, City of Maringa.

Pratt, J.E., and Kay, D.L. (2006), 'Beyond looking backward: is child care a key economic sector?', Journal of the Community Development Society, Vol 37, No 2, pp 23-37.

Pratt, S. (2011), 'Economic linkages and impacts across the Talc', Annals of Tourism Research, Vol 38, No 2, pp 630-650.

Rasmussen, P.N. (1956), Studies in Inter-sectoral Relations, North Holland, Amsterdam.

Reis, H., and Rua, A. (2006), An Input Output Analysis: Linkages vs Leakages, Economic Research Department, Banco de Portugal, Lisbon.

Saito, K., and Kobayashi, S. (2007), The International Linkage of Economic Policy in Lower Mekong Subregion Countries CGE Models, University of Tokyo and Mekong Project, Tokyo.

Secretario, F., Kwangmoon, K., Trinh, B., Nor, V., and Manh, H.D. (2009), Comparative Studies of Indochina Economies (Cambodia, Thailand and Vietnam): An Input Output Approach, Development and Polices Research Center, Hanoi.

Sim, B., Secretario, F., and Suan, E. (2007), Developing an Interregional Input Output Table for Cross Border Economies: An Application to Lao PDR and Thailand, Asian Development Bank, Manila.

Sonis, M., Guihoto, J.J.M., Hewings, G.J.D., and Martins, E.B. (1995a), 'Linkages, key sectors, and structural change: some new perspectives', The Developing Economies, Vol 33, No 3, pp 243-246.

Sonis, M., Hewings, G.J.D., and Guo, J. (1995b), 'A new image of classical key sector analysis: minimum information decomposition of the Leontief inverse', Economic System Research, Vol 12, No 3, pp 401-423.

Surugiu, C., Frent, C., and Surugiu, M. (2009), 'Tourism and its impact upon the Romanian economy: an input output approach', Analele Stiintifice ale Universitatii 'Alexandru Ioan Cuza' din Iasi-Stiinte Economice, Vol 56, pp 355-376.

United Nations (1999), Handbook of National Accounting and Handbook of Input Output Table Compilation and Analysis, United Nations, New York.

UNWTO (2008), Tourism Highlights, United Nations World Tourism Organization, New York.

UNWTO (2009), Tourism Highlights, United Nations World Tourism Organization, New York.

Vavrla, L., and Rojicek, M. (2006), 'System of symmetric input output table compilation and update', Statistika, pp 28-43.

World Travel and Tourism Council (2010), Travel and Tourism Economic Impact of Laos 2010, World Travel and Tourism Council.

Zhou, D., Yanagida, J.F., Chakravorty, U., and Leung, P.S. (1997), 'Estimating economic impacts from tourism', Annals and Tourism Research, Vol 24, No 1, pp 76-89. 


\section{Appendix}

\section{Formulae for deriving different inter-industry linkages}

1. Chenery-Watanabe inter-industry linkages (Beynon et al, 2009)

$$
\begin{gathered}
B L_{i}=\frac{\sum_{i} X_{i j}}{X j}=\frac{\sum_{i} X_{i j}}{\sum_{i}^{n} \sum_{i}^{n} X_{i j}}, \\
F L_{i}=\frac{\sum_{j} X_{i j}}{X_{i}}=\frac{\sum_{j} X_{i j}}{\sum_{j}^{n} \sum_{j}^{n} X_{i j}},
\end{gathered}
$$

where $B L_{j}=$ backward linkage of the $j$ th sector; $X_{i j}=$ amount of commodity $i$ used in the production of commodity $j ; X_{j}=$ gross output of $j$ th sector (column vector: sum of total intermediate purchases and gross value added); $a_{i j}=\mathrm{I}-\mathrm{O}$ coefficient (the amount of $i$ th commodity used in the per unit production of the $j$ th commodity); $F L_{i}$ $=$ Forward linkage of the $i$ th sector; and $X_{i}=$ gross output of $i$ th sector (row vector: sum of the intermediate and final demands).

2. Rasmussen-Hirschman backward and forward linkages (Bonet, 2005; Parré et al, 2002; Sonis et al, 1995)

$$
\begin{aligned}
& B L=(U j)=\frac{b \cdot j / n}{(I-A)^{-1}}, \\
& F L=(U i)=\frac{b \cdot i / n}{(I-A)^{-1}},
\end{aligned}
$$

where $U_{j}=B L=$ backward linkage index; $U i=F L=$ forward linkage index; $(I-A)^{-1}=$ Leontief inverse matrix; $b_{j}=$ column sums of the Leontief inverse matrix; $b_{i}$ = row sums of the Leontief inverse matrix; $b .=$ total sums of the Leontief inverse matrix; and $n=$ number of economic sectors in the matrix.

The interpretations of linkages are as follows: key sectors: both $B L$ and $F L>1$; backward oriented sectors: $B L>1$ and $F L<1$; forward oriented sectors $B L<1$ and $F L>1 ;$ and weak sectors $B L<1$ and $F L<1$.

3. Pure linkages (Bonet, 2005; Sonis et al, 1995a; Sonis et al, 1996b)

$$
\begin{aligned}
& P B L=\Delta_{r} A_{r j} \Delta_{j} Y_{j}, \\
& P F L=\Delta_{j} A_{j r} \Delta_{r} Y_{r},
\end{aligned}
$$

where $A_{j j}=$ squared matrixes of direct inputs of sector $j ; A_{r r}=$ squared matrixes of direct inputs of the rest of the economy (total minus sector $j$ ); $A_{r j}=$ direct inputs bought by the sector $j$ from the rest of the economy; $A_{j r}=\operatorname{direct}$ inputs bought by the rest of the economy from sector $j ; Y_{j}=$ total output of sector $j ; Y_{r}=$ total output of the rest of the economy; $\Delta_{r}=$ changes in output of the rest of the economy; and $\Delta_{j}=$ changes in output of sector $j$. 
4. Weighted linkages (Drejer, 2003)

Weighted backward linkages $\left(U_{r j}\right)=\frac{1 / n \sum_{i}^{n} r_{i} b_{i j}}{1 / n^{2} \sum_{i} \sum_{j} r_{i} b_{i j}}$,

Weighted forward linkages $\left(U_{r i}\right)=\frac{1 / n \sum_{j} r_{j} b_{i j}^{*}}{1 / n^{2} \sum_{i} \sum_{j} r_{j} b_{i j}^{*}}$,

where $n=$ total number of economic sectors; $r=$ weight allocated to the economic sector; $\sum_{j} b_{i j}=$ sum of the row of elements of the Leontief inverse; $\sum_{i} b_{i j}=$ sum of the column elements of the Leontief inverse; and $\sum_{i} \sum_{j} b_{i j}^{*}=$ sum of the overall elements of the Leontief inverse.

5. I-O multiplier product matrix (MPM) (Bonet, 2005; Hewings et al, 1998)

$$
\begin{aligned}
& M P M=A=\left\|a_{i j}\right\| \text { is the direct requirements of the } \mathrm{I}-\mathrm{O} \text { tables. } \\
& M P M=B=\left\|b_{i j}\right\| \text { is the Leontief inverse (SAM) matrix. }
\end{aligned}
$$

6. Self-sufficiency rate analysis (Asra et al, 2006; Secretario et al, 2009)

$$
S S R_{j}=X j / T L D j
$$

where $S S R_{j}=$ self-sufficiency rate of sector $j ; X_{j}=$ gross domestic output of the sector $j$; and $T L D_{j}=$ total domestic demand of the sector $j$. 